\title{
Religiously Motivated Travel and Rural Tourism in Vhembe District of South Africa
}

\author{
Agyapong Gyekye ${ }^{1}$, Emmanuel Oseifuah ${ }^{2}$, Tondani Nethengwe ${ }^{3}$, Fhatuwani Sumbana ${ }^{4}$, Gift \\ Dafuleya $^{5}$ \\ 1,2,3,4,5 University of Venda, P Bag X5050, Thohoyandou, Limpopo Province, South Africa
}

\begin{abstract}
The study investigated the socio-economic impact of religious tourism (UAAC gathering) on the local tourism industry and on surrounding rural communities in Vhembe District Municipality (VDM) of South Africa. Questionnaires were used to collect data on pilgrims (visitors), businesses, and residents during, and immediately after the event. Statistical techniques were used to analyse the data to gain insight into the data as basis for answering the research questions posed in this study. The results revealed that majority of the pilgrims to the UAAC gathering were from the host province of Limpopo. Also, most pilgrims travel to the pilgrimage site solely for religious reasons. Another significant finding is that the average spending per pilgrim by pilgrims from the rest of South Africa is larger than their Limpopo and foreign pilgrim counterparts. Furthermore, the results showed that while businesses were positive about the pilgrimage's contribution to increased sales from their businesses, they at the same time opined that the event does not generate any additional employment. This could be because out of every R100 of pilgrims spending only R2.16 remains in the local economy through leakages. Finally an important finding of the study is overall consensus among residents that the annual pilgrimage gathering promotes morality, improved socialization as well as a sense of feeling good and proud of their community.
\end{abstract}

\section{Introduction}

People usually travel away from their places of residence for different reasons. Each reason of travel is categorised into a type of tourism. For example, extended family voyages or club voyages are categorised as social or group tourism; travelling for business and conferences has been termed economic or business tourism; travelling for political events is named political tourism; travelling across international borders for the purpose of receiving medical care is referred to as medical tourism; trips by athletes as well as visitors of sporting events are termed sports tourism; and that voyage whose participation is motivated either in part or exclusively for religious reasons is termed religious tourism [1]. This study is about religious tourism and its impact on surrounding communities

Religiously motivated travel is considered as one of the oldest and most widespread reasons for travel. There are a number of destinations that have become renowned for their religious tourism resources and attracting large volumes of visitors daily. Sacred places such as shrines, temples, churches, landscape features and ceremonial events are among the most ancient in religious tourism [2]. Similar to other countries, millions of people in South Africa also travel to places of spiritual significance such as religious sites for religious reasons. Over time, religious tourism has had an increased affinity to pilgrimage, cultural and secular tourism to the extent that [3] have used the term tourism pilgrimage to stress this kinship of terms. 
Stark [4] describes religious tourism as a form of tourism that is conducted at religious sites and often includes aspects of religious worship. Thus a religious tourist is someone who engages in tourism but does so at religious sites. [1] adds that religious tourism is a genre of tourism that is exclusively or strongly motivated for religious reasons. Religious tourism, according to him, involves a dynamic element - movement in space, a journey, as well as by a static element - a temporary stay at a place other than the place of residence. This study adopts [4]'s definition of religious tourism.

To the best of our knowledge there is general paucity of studies that have attempted to research the socio-economic impact of religious tourism in South Africa (with the notable exception of recent study by [5] which emphasise economic impact evaluation of religious tourism). This is despite the potential impact that religious pilgrimage may have on a local economy given that travellers require some form of accommodation, food and drink, transportation, and facilities for recreation and shopping on the way, during and after their visit to the sacred sites. Therefore, this study will attempt to fill this research gap by assessing both the social and economic impact of religious tourism on the local tourism industry and on surrounding rural communities in Vhembe District Municipality (VDM).

\section{The setting and description of the case}

The priority areas of South Africa at the national level include rural development. Rural tourism is one of the pathways in which rural development can be achieved. Therefore, this study focuses on a setting that is not only rural but also has a potential for rural tourism. We found such a setting in Vhembe District in the Limpopo province, which is one of the rural and poorest districts in South Africa. In this setting, there is a major religious event that takes place annually and attracts pilgrims from South Africa and neighbouring countries.

It is from this perspective that the study investigates religious tourism in a rural milieu. Religious tourism is also considered by the government as a strategic activity for employment and generation of value to host economies. In particular the socio-economic impacts of religious tourism include influx of people and related social challenges, impacts on local communities and cultural values. Assessing the impacts of religious tourism on local communities will give religious tourism an opportunity to confirm itself as a local agent for development. Religious tourism in a rural setting is therefore a salient case.

The organisation behind this large religious event is the United African Apostolic Church (UAAC). It is the second largest African initiated church in South Africa. The church believes that God has called them to reach the "unchurched" of different communities by providing caring structures for families, diversity in worship, small caring groups, and knowledge of spiritual gifts. The mission of the church is to empower youth to develop their DREAMS, an acronym for Dynamic Realizable Efforts to Attain and Maintain Success. With this mission, the church dedicates itself to partner each youth with a plan and then making sure that the plan is executed and evaluated each year.

The yearly gatherings, which form the bases of our case study, usually take place in the third week of September. The first day of the gathering is Monday. Here, only senior citizens and elderly members of the church attend. These are usually the people who are pensioners or at least are out of employment due to old age. The church supplies attendees with food from Monday till Thursday. Branches from all over the country contribute this food. The basic task for these members who arrive first for the gathering is to pray for the church and for travelling mercies for all those who will be coming for the gathering on Friday until Sunday.

Friday marks the day when the general conference is open to everyone and thus gathers momentum. The first main service is held on Friday at $10 \mathrm{pm}$. Then on Saturday morning, members from other provinces and countries arrive. By $8 \mathrm{am}$ in the morning, the women service in the main church will be expected to start. 
This service does not involve men. Instead they will be somewhere around the compound carrying out other church related business. From $2-5 \mathrm{pm}$, the youth gather in the main church, where they are given the keynote address by the Bishop. Different choirs from different branches of the church take turn to sing from 7-10pm. Sunday is the main day for all pilgrims - men, women and youth. Senior government officials also attend on this day, including Ministers, Executive Mayors, and the King of VhaVenda. Government officials from other countries, for example Zimbabwe, have also graced the gathering. The event reaches its climax when The Arch Bishop delivers the annual address.

The pilgrims mainly attend this gathering for the purpose of attaining blessings. This is also a period of self-denial for the pilgrims and revival. As such, most of them do not have time to move out of the site and search for accommodation. If anything, they are so comfortable to sleep in buses, perhaps one way of demonstrating self-denial and humbling themselves before their God.

\section{Research methodology}

Pilgrims (Visitors), businesses, and residents' surveys were conducted using questionnaires to solicit data for the study during, and immediately after the religious gathering.

\subsection{Surveys}

Three types of surveys were conducted. The first survey was for the analysis of pilgrim spending patterns. The data was collected using a structured questionnaire. The survey was conducted by administering the questionnaire to pilgrims at Ha-Mavhunga from 20-22 September 2013. A total of 508 questionnaires were randomly administered over the three-day period. The second survey was on local businesses. Here, all (46) local businesses on the main access roads to the Ha-Mavhunga site together with local vendors (hawkers) were selected for inclusion in the survey. The third survey focused on surrounding communities of the UAAC gathering where a systematic random sample of 73 dwelling units in the vicinity of the UAAC pilgrimage site in the Nzhelele valley was selected to assess the social impact of the religious gathering. Data collection was was carried out on the $12^{\text {th }}$ and $13^{\text {th }}$ October 2013.

Information gathered during our survey of businesses in the local host community indicated that a significant proportion of the goods sold by these businesses to pilgrims during the gathering were "imported" products (i.e. procured from outside of the area). Therefore, to obtain a more realistic estimation of the magnitude of the spending that accrues to the local economy, we had to ask the local businesses about the percentage of their stocks that they purchase from outside of the study region. In other words, what is the size of "leakages" from pilgrims spending (on the goods from local businesses) which directly impacts on the indirect effects of the initial pilgrim spending, and as a consequence the size multiplier?". This estimate was in turn used to calculate the simple Keynesian multiplier (=1/leakage) for use in determining the total economic impact of pilgrim spending in the study area.

\subsubsection{Estimating Social Impact of UAAC Gathering}

The data for the social impact assessment was captured and analysed using SPSS version 21. Descriptive statistics were generated for the socio-demographic variables as well as for the 14 individual impact statements which were subsequently ranked to ascertain the statements with overall high agreement by host residents. Crosstabs between respondents' socio-demographic characteristics and impact statements were done to further the analysis. 


\section{Results}

\subsection{Pilgrim profile}

Our survey results indicate that the vast majority of pilgrims to the September gathering of the UAAC Church are repeat pilgrims with $77 \%$ of them having attended the gathering before.

Table 1. Composition of sample

\begin{tabular}{|c|c|c|}
\hline & Numbers & Percentage \\
\hline \multicolumn{3}{|l|}{ Locals } \\
\hline Limpopo & 312 & 62.4 \\
\hline \multicolumn{3}{|l|}{ Rest of South Africa } \\
\hline Eastern Cape & 4 & 0.8 \\
\hline Free State & 23 & 4.6 \\
\hline Gauteng & 100 & 20 \\
\hline Kwazulu-Natal & 3 & 0.6 \\
\hline Mpumalanga & 17 & 3.4 \\
\hline North West & 13 & 2.6 \\
\hline \multicolumn{3}{|l|}{ Outside South Africa } \\
\hline Lesotho & 3 & 0.6 \\
\hline Zambia & 2 & 0.4 \\
\hline Zimbabwe & 23 & 4.6 \\
\hline \multicolumn{3}{|l|}{ Age (years) } \\
\hline $16-24$ & 146 & 28.7 \\
\hline $25-34$ & 159 & 31.3 \\
\hline $35-44$ & 96 & 18.9 \\
\hline $45-54$ & 58 & 11.4 \\
\hline $55-64$ & 17 & 3.3 \\
\hline $65+$ & 13 & 2.6 \\
\hline \multicolumn{3}{|l|}{ Gender } \\
\hline Female & 234 & 46.1 \\
\hline Male & 257 & 50.6 \\
\hline \multicolumn{3}{|l|}{ Group Dynamics } \\
\hline On my own & 81 & 15.9 \\
\hline With adults & 28 & 5.5 \\
\hline With adults and children & 59 & 11.6 \\
\hline With a group & 268 & 52.8 \\
\hline With family & 34 & 6.7 \\
\hline With friends & 31 & 6.1 \\
\hline
\end{tabular}

Source: Calculated from Survey Data

Table 1 shows that, majority of the pilgrims to the UAAC gathering $(62.4 \%)$ were from the host province of Limpopo. Over a third (31.9\%) of the pilgrims was from the rest of South Africa, with majority of these hailing from the Gauteng Province. Of the $5.5 \%$ of the pilgrims who came from outside of South Africa, overwhelming majority (85\%) travelled from Zimbabwe. More than half of the pilgrims to the UAAC gathering came with a group of other pilgrims, with group size of members averaging 40. These groups travel mostly in hired buses or taxis to ferry their members to the pilgrimage site. As can be seen in table 2, most respondents $(71.3 \%)$ used hired vehicles and public transport to come to the pilgrim site. 
Table 2. Mode of Transport

\begin{tabular}{|l|c|c|}
\hline Travel Mode & Frequency & Percent \\
\hline Private car & 85 & 16.7 \\
\hline Hired vehicle & 167 & 32.9 \\
\hline Public transport & 195 & 38.4 \\
\hline On foot & 32 & 6.3 \\
\hline Other & 21 & 4.1 \\
\hline
\end{tabular}

Source: Calculated from Survey Data

It is interesting to note that, contrary to conventional wisdom, there were more male pilgrims than female pilgrims, with $60 \%$ of the pilgrims being in the youth age of below 35 years. When asked whether they visited anywhere else in Limpopo aside from the gathering site, most pilgrims (77\%) responded that they never visited any other place in Limpopo, signifying that they came solely for the religious ritual.

\subsection{Descriptive analysis on spending}

When asked if they have made any purchases since their arrival at Ha-Mavhunga, and from which source, $41 \%$ of pilgrims responded that they made purchases inside the site of the gathering, a further $32 \%$ made their purchases from Vendors (outside the gathering site) while $21 \%$ came with whatever they needed.

Table 3. Visitor Expenditure Patterns

\begin{tabular}{lcll}
\hline & Numbers & $\begin{array}{l}\text { Total } \\
\text { Expenditures }\end{array}$ & $\begin{array}{l}\text { Average } \\
\text { Spending per } \\
\text { Visitor }\end{array}$ \\
\hline SEGMENTS: & 312 & $\mathrm{R} 243617$ & $\mathrm{R} 780.82$ \\
Locals & 160 & $\mathrm{R} 225490.7$ & $\mathrm{R} 1409.32$ \\
Rest of South Africa & 28 & $\mathrm{R} 27887$ & $\mathrm{R} 995.96$ \\
Outside South Africa & & & \\
CATEGORIES: & 76 & $\mathrm{R} 59033.00$ & $\mathrm{R} 776.75$ \\
Transport & 143 & $\mathrm{R} 281963.00$ & $\mathrm{R} 1971.77$ \\
Private car & 175 & $\mathrm{R} 76362.00$ & $\mathrm{R} 436.35$ \\
Hired vehicle & & & \\
Public transport & 207 & $\mathrm{R} 18373.99$ & $\mathrm{R} 88.76$ \\
Food and Beverages & 154 & $\mathrm{R} 19372.70$ & $\mathrm{R} 125.80$ \\
Spending within Camp site & 2 & $\mathrm{R} 500$ & $\mathrm{R} 250$ \\
Spending on Vendors & 4 & $\mathrm{R} 13649.00$ & $\mathrm{R} 3412.25$ \\
Accommodation & & & \\
Shopping (Souvenirs etc) & & & \\
\hline
\end{tabular}

Source: Calculated from Survey Data

The average spending per pilgrim on the various categories is shown in table 3 . The table indicates that average spending by pilgrims from the rest of South Africa is more than their Limpopo and foreign pilgrim counterparts. It is not surprising that pilgrims from other South African provinces on the average spends more than their foreign counterparts, as most of the foreign pilgrims are from Zimbabwe origins which are closer to the pilgrim site at Ha-Mavhunga (Limpopo) than most origins in the rest of South Africa. It should be noted that most expenditures are on transport, which largely depends on the distance from origin to the pilgrimage site. In addition the numbers of foreign pilgrims are rather small compared to others (23 out of 508 sampled pilgrims). 


\subsection{Descriptive summary from businesses}

Businesses were requested to express their opinions on the annual UAAC gathering on a number of issues which impacts on their businesses. Table 4 indicates that all businesses with the notable exception of vendors surveyed were positive (agree or strongly agree) that the pilgrimage contributes to increased sales from their businesses.

Table 4.The pilgrimage gathering increases sales

\begin{tabular}{|l|c|c|c|c|}
\hline Business type & $\begin{array}{c}\text { Strongly Disagree/ } \\
\text { Disagree }\end{array}$ & No Difference & $\begin{array}{c}\text { Agree/ } \\
\text { Strongly Agree }\end{array}$ & Raw Totals \\
\hline Fuel station & 0 & $7 \%$ & $83 \%$ & 6 \\
\hline Food and beverage & 0 & $20 \%$ & $80 \%$ & 10 \\
\hline Car wash & 0 & $19 \%$ & $81 \%$ & 16 \\
\hline Vendor & $7 \%$ & $50 \%$ & $43 \%$ & 14 \\
\hline
\end{tabular}

Source: Calculated from Survey Data

Table 5. During religious gathering, employment increases in my business

\begin{tabular}{|l|c|c|c|c|}
\hline Business type & $\begin{array}{c}\text { Strongly disagree/ } \\
\text { Disagree }\end{array}$ & No Difference & $\begin{array}{c}\text { Agree/ } \\
\text { Strongly agree }\end{array}$ & Raw Totals \\
\hline Fuel Station & $100 \%$ & 0 & 0 & 6 \\
\hline $\begin{array}{l}\text { Food and } \\
\text { Beverages }\end{array}$ & $60 \%$ & $10 \%$ & $30 \%$ & 10 \\
\hline Car Wash & $44 \%$ & $9 \%$ & $50 \%$ & 16 \\
\hline Vendor & $62 \%$ & 0 & $38 \%$ & 13 \\
\hline
\end{tabular}

Source: Calculated from Survey Data

However, fuel stations and food and beverages felt that the pilgrimage gathering does not generate any additional employment (see Table 5). Those that felt the gathering generates employment are the vendors and car washes. This is probably so because as the numbers of vehicles and people increase, more employees are needed to service them. Furthermore, hiring and scaling down of these employees is easy as there are no formal contracts involved. This is unlike the case of fuel stations and food and beverages that may be having semi-formal or formal contracts with their employees. As such hiring temporarily is a bit difficult and almost unnecessary given the high leakages in these sectors.

The direct sales from the pilgrimage gathering was estimated to be R99.1 million $(100,000[(0.624 * 1059.28))+(0.319 * 104.56)+(0.055 * 3412.25)]$ calculated from an estimated figure of 100,000 pilgrims assumed to have attended the gathering.

To determine the proportion of spending that accrues to the local economy, information was obtained from the local businesses about the amount of "imported" products sold. Table 6 shows the average percentage of stock procured from outside of the 50 kilometre radius of the study area. These "leakages" were used to calculate a simple Keynesian multiplier, which was in turn used to calculate total sales effect of pilgrim spending

Table 6. Leakage According to Spending Category

\begin{tabular}{|l|l|l|}
\hline Type of Business & $\begin{array}{l}\text { Number of Interviewed } \\
\text { Businesses }\end{array}$ & $\begin{array}{l}\text { Average percentage of stock } \\
\text { bought outside 50km Radius }\end{array}$ \\
\hline Petrol Station (transport) & 6 & 90 \\
\hline Food and beverages & 10 & 25 \\
\hline Car wash & 16 & 5 \\
\hline Vendor & 14 & 90 \\
\hline
\end{tabular}

Source: Calculated from Survey Data 


\section{Estimated leakage}

The Multiplier (1/leakage) becomes $-1 / 46.303=0.0216$.

The total sales effect, which is an indicator of spending accruing to the local economy, is R2.14 million. The perception of businesses relating to increased sales during pilgrimage gathering is somewhat justified.

\subsection{Opinions from households on social impacts}

A sample of local residents was asked to express their opinions about the annual UAAC gathering on various socio-economic issues. Table 7 presents the mean of the Likert Scale responses from the residents. A higher mean implies a response in the affirmative, that is, agree or strongly agree (see scale below table 7). Thus the mean responses in table 7 shows that creation of opportunities for local business, generating additional income, promotion of morality, improved socialization, encouraging cohesion as well as promotion of courtesy were perceived by residents as resulting from the religious gathering. On the other hand, the community perceives that the gathering does not create employment, does not increase prices and does not cause pollution.

Table 7. Household Opinions on Social Impact

\begin{tabular}{lcc}
\hline Social Impact & Mean & Standard Deviation \\
\hline Pilgrimage generates employment & 2.21 & 0.773 \\
Pilgrimage generates additional income & 4.45 & 0.501 \\
Pilgrimage creates opportunities for local businesses & 4.51 & 0.53 \\
Pilgrimage makes us feel good and proud & 3.42 & 1.166 \\
Pilgrimage encourages cohesion & 4.33 & 0.751 \\
Pilgrimage promotes courtesy & 4.25 & 0.765 \\
Pilgrimages improves socialization & 4.36 & 0.512 \\
Pilgrimage promotes morality & 4.43 & 0.577 \\
Pilgrimage cause pollution & 2.53 & 1.244 \\
Pilgrimage increases prices in the area & 2.6 & 3.74 \\
\hline Source: Calculat
\end{tabular}

Source: Calculated from Survey Data

The study further analyzed household opinions on social impacts in terms of crosstabs between gender and social impacts of interest. In addition, the study also assessed crosstabs between degree of religiousity and selected variables of social impact. This was done to check if female responses were different from male responses. Also it was done to check if responses especially those that pertain to issues such as pollution could be different depending on the degree of religiosity. None of these differences were significant (see appendix 4 and 5).

\section{Conclusion}

The study was undertaken to provide insight into the spending behaviour of pilgrims to, arguably, the second largest religious pilgrimage in South Africa- the annual gathering of the United African Apostolic Church in Ha-Mavhunga in the Vhembe District. The study further explored the perceptions 
of local residents and businesses on the impact of the religious gathering. From the analysis the following conclusions can be drawn. Majority of the pilgrims to the UAAC gathering were from the host province of Limpopo. Over a third of the pilgrims were from the rest of South Africa. Most of the pilgrims who came from outside of South Africa travelled from Zimbabwe. An important finding of the study is that most pilgrims travel to the pilgrimage site solely for religious ritual and do not visit other parts of the host province of Limpopo. The average spending per pilgrim by pilgrims from the rest of South Africa was larger than their Limpopo and foreign pilgrim counterparts. The average spending of tourists from neighbouring countries in South Africa has been reported by [5] to be approximately R5500 in 2010, which is five times higher than the figure we report. It is however not surprising those pilgrims from other South African provinces on the average spends more than their foreign counterparts, as most of the foreign pilgrims are from Zimbabwe origins which are closer to the pilgrim site at Ha-Mavhunga (Limpopo) than most origins in the rest of South Africa. It should be noted that most expenditures are on transport, which largely depends on the distance from origin to the pilgrimage site.

The leakages from the local economy were found to be high largely due to the demarcation of the impact area (50 kilometre radius) for this study, but also due to the production structure which is largely devoid of manufacturing sector from which many consumption goods are procured by businesses. These "leakages" were used to calculate a simple Keynesian multiplier, which was in turn used to calculate total sales effect of pilgrim spending. The size of the multiplier indicates that out of every R100 of pilgrims spending only R2.16 remain in the local economy.

While businesses were positive about the pilgrimage's contribution to increased sales from their businesses, they at the same time opined that the pilgrimage gathering does not generate any additional employment. This may be largely attributable to the substantial leakages from the local economy through "import " of supplies from outside the local economy thereby limiting local employment generation potential that could be credited to the production of these supplies. Residents perceived positive community image followed by promotion of morality and enhancing social cohesion as the leading benefits of the religious gathering. At the same time residents view littering and increased prices of goods as negatively impacting on the community, although they regard the positive impacts to outweigh the negatives, and would therefore like the pilgrim population to grow annually.

\section{Recommendations}

1 It is recommended that, for significant positive impact of the annual UAAC pilgrimage to be realized in the local economy, serious discussions should be initiated within the District Municipality, in an effort to empower more local peoples' ownership of pilgrimage related businesses, in particular transport businesses in order to generate income and employment in this rural municipality

2 Residents of the host rural community of the annual gathering perceived positive impacts of the religious gathering to outweigh the negatives, and would therefore like the pilgrim population to grow annually. Based on this perception, it is recommended that, for residents' wishes to be realized, and for this religious tourism to flourish, the provision of basic infrastructure including water, sanitation, accommodation and access roads to the pilgrimage site, which the study found to be inadequate, requires the intervention of provincial or local municipality to provide these basic services.

3 Finally, for South Africa as a country, this study has shed some light on the advantage of the economic, social and religious benefits that accrue from development and promotion of religious tourism. If travels to faith based camps, holy places and religious conventions are encouraged by government at all levels, religious tourism will not only be brought to the lime-light, but will also help in securing a prominent position for the country on the world tourism map. 


\section{ICTR}

\section{References}

1. G. Rinschede (1992). Forms of religious tourism. Annals of Tourism Research.19, (1) 51-67.

2. M. Nolan, S. Nolan (1992). Religious sites as tourism attractions in Europe. Annals of Tourism Research 19 (1) 68-78.

3. L. Hudman, RH. Jackson (1995). Pilgrimage tourism and English cathedrals: The role of religion in travel. Tourists Review 50 (4), 40-48.

4. D.J Stark (2009), "Religious Tourism in Roman Greece" Theses and Dissertations (Comprehensive).Paper 951.

5. A. Saayman, M. Saayman, A. Gyekye (2013). Perspective on the Regional Economic Value of a Pilgrimage. International Journal of Tourism Research. DOI: 10.1002/jtr.1936 